\title{
Monitoramento do Banco de Sementes de Plantas Daninhas em Áreas Com Cana-de-Açúcar Colmida Mecanicamente ${ }^{1}$
}

\author{
Weed Infestation Maps under Different Sugarcane Harvest Systems \\ MONQUERO, P.A. ${ }^{2}$, SILVA, P.V. ${ }^{3}$, HIRATA, A.C.S. ${ }^{4}$ e MARTINS, F.R.A. ${ }^{5}$
}

\begin{abstract}
RESUMO - O objetivo deste trabalho foi monitorar o banco de sementes de área cultivada com cana-de-açúcar colhida mecanicamente por seis anos e um ano, utilizando-se técnicas de agricultura de precisão. As amostragens de solo para determinação do banco de sementes foram realizadas utilizando-se grade amostral regular de 1,6 ha. Os mapas de infestação foram obtidos pela técnica de interpolação por krigagem. Observou-se que o talhão de cana colhida mecanicamente por seis anos apresentou menor potencial de infestação de várias espécies de plantas daninhas em relação ao talhão onde esse manejo foi adotado recentemente. Plantas daninhas monocotiledôneas, como Cyperus rotundus e Brachiaria decumbens, foram reduzidas pela adoção da colheita mecanizada. Todavia, algumas dicotiledôneas foram selecionadas, como as dos gêneros Ipomoea e Euphorbia. Verificou-se que a palha de cana-de-açúcar, em sistemas de cana-crua, pode ser utilizada como fator de supressão e seleção de várias espécies.
\end{abstract}

Palavras-chave: agricultura de precisão, banco de sementes, variabilidade espacial.

\begin{abstract}
The objective of this work was to identify the differences between the seedbank of area cultivated with sugarcane picked mechanically by six years and for one year, being used techniques of agriculture of precision. The soil sampling for seedbank determination were performed using a 1,6 ha regular sampling grid. The weed infestation maps were obtained by the kriging interpolation technique. The green sugarcane field presented lowerweed infestation potential compared to the burnt sugarcane field, specially the monocotyledonous species like Cyperus rotundus and Brachiaria decumbens. However, some dicotyledonous species can be selected, such as the Ipomoea and Euphorbia and that sugarcane straw can be used as a suppression/selection factor for various species.
\end{abstract}

Keywords: precision agriculture, seedbank, spacial variability.

\section{INTRODUÇÃO}

A safra de cana-de-açúcar 2008/09 deverá ser a maior da história, com 498,1 milhões de toneladas colhidas. Segundo projeção da entidade, a safra que se iniciou neste mês será $16 \%$ maior do que a anterior, quando foram colhidas 431,2 milhões de toneladas de cana. A produção de açúcar deve ser 9\% maior do que o resultado obtido no ano anterior e deverá chegar a 28,6 milhões de toneladas do produto. Além disso, a produção total de álcool deverá ter crescimento de $19 \%$, com um total de 24,3 bilhões de litros. Desses, 7,6 bilhões serão de álcool anidro e 16,6 bilhões, de álcool hidratado (Unica, 2009).

Recebido para publicação em 7.12.2009 e na forma revisada em 18.2.2011.

2 Professora Adjunta do Centro de Ciências Agrárias, Universidade Federal de São Carlos - CCA/UFSCar, Rodovia Anhanguera, km 174, Araras, São Paulo, <pamonque@cca.ufscar.br>; ${ }^{3}$ Aluno de graduação, CCA/UFSCar, <brunom@agroexata.com.br>, <paulov@cca.ufscar.br>; ${ }^{4}$ Pesquisadora do APTA/Polo Regional da Alta Sorocabana, <andreiacs@apta.sp.gov.br>; ${ }^{5}$ Eng ${ }^{0}-A g r{ }^{0}$., AGROEXATA, <fernando@agroexata.com.br> 
Com o aumento da área cultivada, aumentou também a preocupação com os impactos ambientais e sociais causados por essa cultura, levando à proibição da queimada em canaviais no Estado de São Paulo, segundo esquema de restrições legais progressivas até o ano de 2021, em áreas com possibilidade de mecanização total da colheita, e até 2031 para as demais áreas (Decreto no 47.700 de 11/3/ 2003, que regulamenta a Lei no 11.241 de $19 /$ 9/2002) (Timossi \& Durigan, 2006). Na colheita mecanizada sem queima, as folhas, bainhas, ponteiros, além de quantidade variável de pedaços de colmo, são cortados, triturados e lançados sobre a superfície do solo, formando a cobertura de palha. Segundo Trivelin et al. (1996), essa quantidade de palha de canaviais colhidos sem queima varia de 10 a $30 \mathrm{t} \mathrm{ha}^{-1}$. O grande volume de palha sobre a cana-soca causa falha na rebrota, especialmente nas variedades melhoradas que foram desenvolvidas para o sistema de colheita com queima, o qual favorecia maior taxa de emergência da cana-soca. Ademais, estudos sob sistema de colheita mecanizada e manual mostraram que a alteração do sistema de colheita manual para mecanizada reduz a amplitude térmica e aumenta o teor de água e de matéria orgânica do solo (Vasconcelos, 2002).

A cobertura morta ocasiona mudanças químicas, físicas e biológicas no solo e pode provocar seleção da comunidade infestante, suprimindo a infestação de plantas daninhas normalmente consideradas importantes nos canaviais, como Digitaria horizontalis, Brachiaria plantaginea, B. decumbens e Panicum maximum (Velini et al., 2000; Medeiros, 2001; Gravena et al., 2004). No entanto, estão surgindo plantas-problema no sistema de canacrua, como Euphorbia heterophylla e Ipomoea grandifolia (Martins et al., 1999; Monquero et al., 2008).

Os efeitos físicos da cobertura morta podem ser atribuídos à filtragem da luz, à quantidade e qualidade do comprimento das ondas luminosas e à manutenção da temperatura com menores oscilações (Theisen \& Vidal, 1999). A luz, a temperatura, a umidade e suas alterações são os mais importantes fatores ambientais para se provocar a superação da dormência das sementes de diversas espécies de plantas daninhas (Ruedell, 1995).
A cobertura de palha favorece a redução no início do crescimento ativo do embrião das sementes fotoblásticas positivas e de sementes que necessitam de alternância de temperatura para germinar (Paes \& Rezende, 2001). Essa adaptação é considerada um mecanismo natural de defesa das espécies, pelo fato de as sementes não germinarem em maiores profundidades no solo, onde a temperatura é sempre mais constante. O efeito físico da cobertura morta também reduz a sobrevivência de plantas daninhas com pequena quantidade de reservas nas sementes. Segundo Pitelli (1998), muitas vezes, as reservas não são suficientes para garantir a sobrevivência de plântulas no espaço percorrido dentro da cobertura morta, para ter acesso à luz e iniciar o processo fotossintético. A cobertura do solo pode atuar também como barreira física, impedindo a incidência de luz e a realização de fotossintese por aquelas plântulas que conseguiram emergir do solo (Azania et al., 2002) e dificultando a emergência de várias espécies de plantas daninhas, devido ao sombreamento (Severino \& Christoffoleti, 2001; Constantin \& Oliveira Junior, 2005) e à consequente redução da amplitude térmica do solo (Severino \& Christoffoleti, 2001).

Além dos efeitos químicos e físicos, existem os efeitos biológicos, que se devem à interferência dos resíduos vegetais na sobrevivência do banco de sementes (Gomes Jr. \& Christoffoleti, 2008). As sementes de plantas daninhas produzidas após a adoção do sistema de plantio direto ficam depositadas na camada superficial do solo, onde estão suscetiveis à ação de predadores de grande porte, como pássaros e roedores, além de outros animais de pequeno porte, como insetos, moluscos e crustáceos (Kremer \& Spencer, 1989), que as danificam fisicamente, afetando sua viabilidade (Vidal \& Theisen, 1999).

Nesse sentido, uma predição precisa da emergência do banco de sementes de plantas daninhas permitiria aos agricultores o planejamento mais eficiente do controle da infestação e a aplicação mais adequada de herbicidas em condições de pré-emergência (Cardina \& Sparrow, 1996). Segundo Cardina et al. (1997), o mapeamento do banco de sementes de plantas daninhas, quando feito criteriosamente, pode ser utilizado para previsão dos locais de 
infestação em cultivos posteriores. Para isso, Luschei et al. (1998) relataram que a estimativa qualitativa e quantitativa das sementes no banco pode ser acompanhada pela germinação direta nas amostras do solo ou pela extração física ou química das sementes associada por ensaios de viabilidade.

A manutenção da palha sobre a superfície do solo pode, simultaneamente, reduzir o potencial de infestação das plantas daninhas, mas também dificulta o desempenho dos herbicidas, uma vez que a água de chuva se torna a principal responsável pelo transporte do herbicida até a superficie do solo (Maciel \& Velini, 2005; Simoni et al., 2006).

Na escolha de um herbicida, deve-se considerar o tipo de planta daninha presente na área, o nível de infestação, o estádio de desenvolvimento em que se encontram, a textura e o teor de matéria orgânica do solo, o estádio de desenvolvimento da cultura, além do custo do controle. Em vista disso, o presente trabalho teve como objetivo monitorar o banco de sementes de plantas daninhas mais significativas em duas áreas com colheita mecanizada de cana-de-açúcar.

\section{MATERIAL E MÉTODOS}

A coleta de solo para o experimento foi realizada na Usina Santa Lúcia, no município de Araras-SP, localizado em latitude de $22^{\circ} 21^{\prime} 25^{\prime \prime}$ sul e longitude de $47^{\circ} 23^{\prime} 03^{\prime \prime}$ oeste, com altitude de $629 \mathrm{~m}$. O clima, pela classificação de Köppen, é do tipo Cwa, ou seja, mesotérmico com verões quentes e úmidos e invernos secos. O monitoramento foi feito em duas áreas em sequência à avaliação realizada em 2006 - ocasião em que em uma área havia colheita mecanizada desde 2003 e, na outra, corte manual (Monquero et al., 2008). Em 2008, o talhão com colheita manual também passou a ser colhido mecanicamente; portanto, avaliou-se uma área (talhão 80) com corte mecânico há seis anos e outra (talhão 13) com um ano apenas de colheita mecanizada (Figura 1). A variedade cultivada foi a RB 85-5453, no sétimo corte.

O histórico de manejo de plantas daninhas registrado em anos consecutivos na área indicou a utilização de herbicidas mimetizadores da auxina $(2,4-D)$ no controle de plantas daninhas de folhas largas e de inibidores do fotossistema II (metribuzin), usado no controle de gramineas como Brachiaria decumbens.

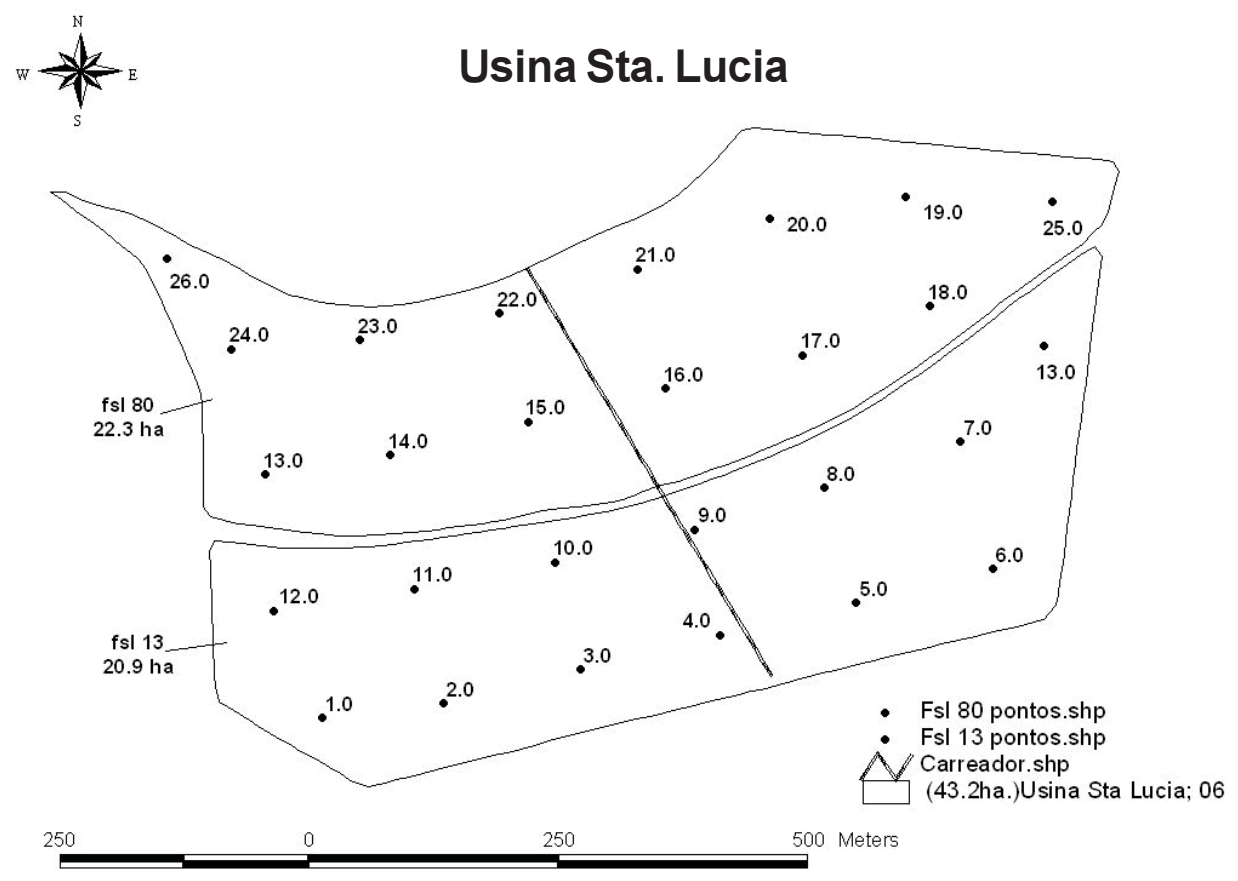

Talhão fsl 80 - área de cana-crua há seis anos; Talhão fsl 13 - área de cana-crua há um ano.

Figura 1 - Mapa dos pontos georreferenciados - Usina Santa Lúcia, Araras-SP. 
Antes das avaliações do banco de sementes foi amostrada a quantidade média de palha dos talhões com cana-crua, utilizando-se um quadrado inventário $\left(1 \mathrm{~m}^{2}\right)$ lançado na área em vários pontos. A área com cana-crua foi dividida em uma grade quadrada, perfazendo 14 pontos, e a de cana colhida após queima, em 13 pontos; cada ponto cobriu uma área de cerca de 1,6 ha.

As coordenadas do perímetro da área e do ponto central das grades de amostragem foram determinadas com equipamento de sistema de posicionamento global, modelo Garmin Vista, e um Pocket PC Ipaq 3600, equipado com o software Field Rover II, para navegação no campo. Para cada ponto georreferenciado, foram coletadas 13 subamostras de 0 a $20 \mathrm{~cm}$, em forma de cruz, utilizando-se um trado holandês de $5 \mathrm{~cm}$ de diâmetro, perfazendo um total de 27 amostras compostas de $1,0 \mathrm{~kg}$ de solo.

Para verificar a porcentagem de germinação do banco de sementes, as amostras de solo coletadas na área experimental foram acondicionadas separadamente em bandejas com $5 \mathrm{~cm}$ de profundidade, em casa de vegetação. Após cada fluxo de emergência, as plantas foram identificadas, contadas e retiradas das bandejas. Aos 45 dias após a instalação, foi realizado um novo revolvimento do solo, para estimular novos fluxos de emergência. A quantificação das plântulas foi realizada até 90 dias após a instalação. Na confecção dos mapas de distribuição espacial foram utilizadas as plantas daninhas de maior ocorrência na área experimental.

Os dados obtidos foram inseridos no ToolboxLite, software de SIG (Sistema de Informações Georreferenciadas), onde as informações foram cruzadas e interpoladas, constituindo como resultado os mapas de infestação de plantas daninhas.

\section{RESULTADOS E DISCUSSÃO}

A quantidade de palha depositada sobre o solo foi de $10 \mathrm{t} \mathrm{ha}^{-1}$. Em 2006, as monocotiledôneas concentraram-se na área colhida após a queima do canavial, com valores variando de 260 a 2.340 sementes viáveis $\mathrm{m}^{-2}$, enquanto na área colhida mecanicamente os valores variaram de 260 a 1.600 sementes viáveis $\mathrm{m}^{-2}$ (Figura 2). Em 2009, os valores de monocotiledôneas variaram de 260 a 1.040 sementes viáveis $\mathrm{m}^{-2}$, sendo encontrados em ambos os talhões, inclusive naquele com colheita mecânica há seis anos. Comparando os mapas de infestação de 2006 e 2009, observa-se que houve disseminação das monocotiledôneas para uma área maior dos talhões, embora com redução dos pontos de concentração de sementes.

Na Figura 3, pode ser analisada a dinâmica do banco de sementes das plantas daninhas dicotiledôneas. Em 2006, as dicotiledôneas ocorreram em maior quantidade e diversidade que as monocotiledôneas em ambas as áreas, porém a concentração foi maior na área colhida após a queima do canavial, com reboleiras dentro do intervalo de 15.600 a 36.400 sementes viáveis $\mathrm{m}^{-2}$, ocupando uma área de aproximadamente 3,4 ha. Em 2009, houve redução na infestação das dicotiledôneas em ambos os talhões, sendo os valores máximos reduzidos de 37.180 para 2.340 sementes viáveis $\mathrm{m}^{-2}$, principalmente no talhão com colheita mecanizada há um ano, o que pode ser devido ao efeito da palha.

Entre as monocotiledôneas, observou-se que apenas Cyperus rotundus e Brachiaria decumbens apresentaram maior ocorrência (Figuras 4 e 5). Em 2006, o banco de sementes de $B$. decumbens foi maior e mais bem distribuído no manejo com queima seguido de colheita manual. Todavia, em 2009, o banco de sementes foi reduzido nos dois manejos, sendo inexistente no sistema de colheita mecanizada há seis anos, e verificada apenas uma pequena mancha com a presença de $B$. decumbens, equivalente a $1,6 \mathrm{ha}^{-1}$ ou $3,8 \%$ do talhão colhido mecanicamente desde 2008 . Em relação a $C$. rotundus, constatou-se grande potencial de infestação no sistema com queima prévia em relação à colheita mecanizada na avaliação de 2006; entretanto, em 2009, sua presença foi menos marcante em ambos os talhões. Trabalhos realizados por Silva et al. (2003) e Durigan et al. (2004) demonstram que o número de manifestações epígeas da tiririca foi reduzido pela cobertura com palha. Novo (2004) verificou redução linear no número de brotações com o aumento na quantidade de palha, diminuindo a biomassa da parte aérea, sobretudo nas plantas de tiririca originadas de tubérculos pequenos. 


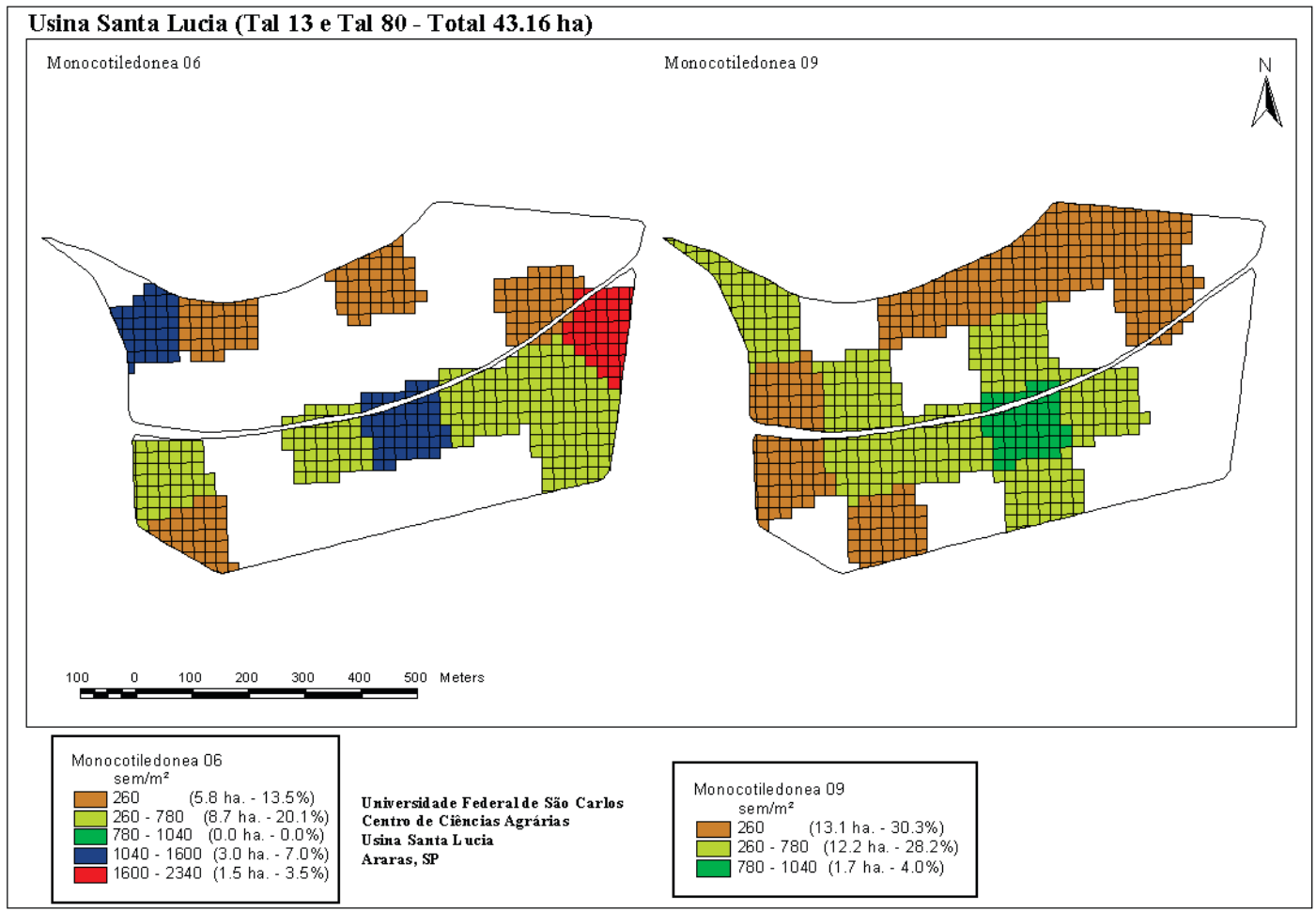

Figura 2 - Mapas de infestação de monocotiledôneas em área cultivada com cana-de-açúcar em sistema de cana-crua, em 2006 e 2009.

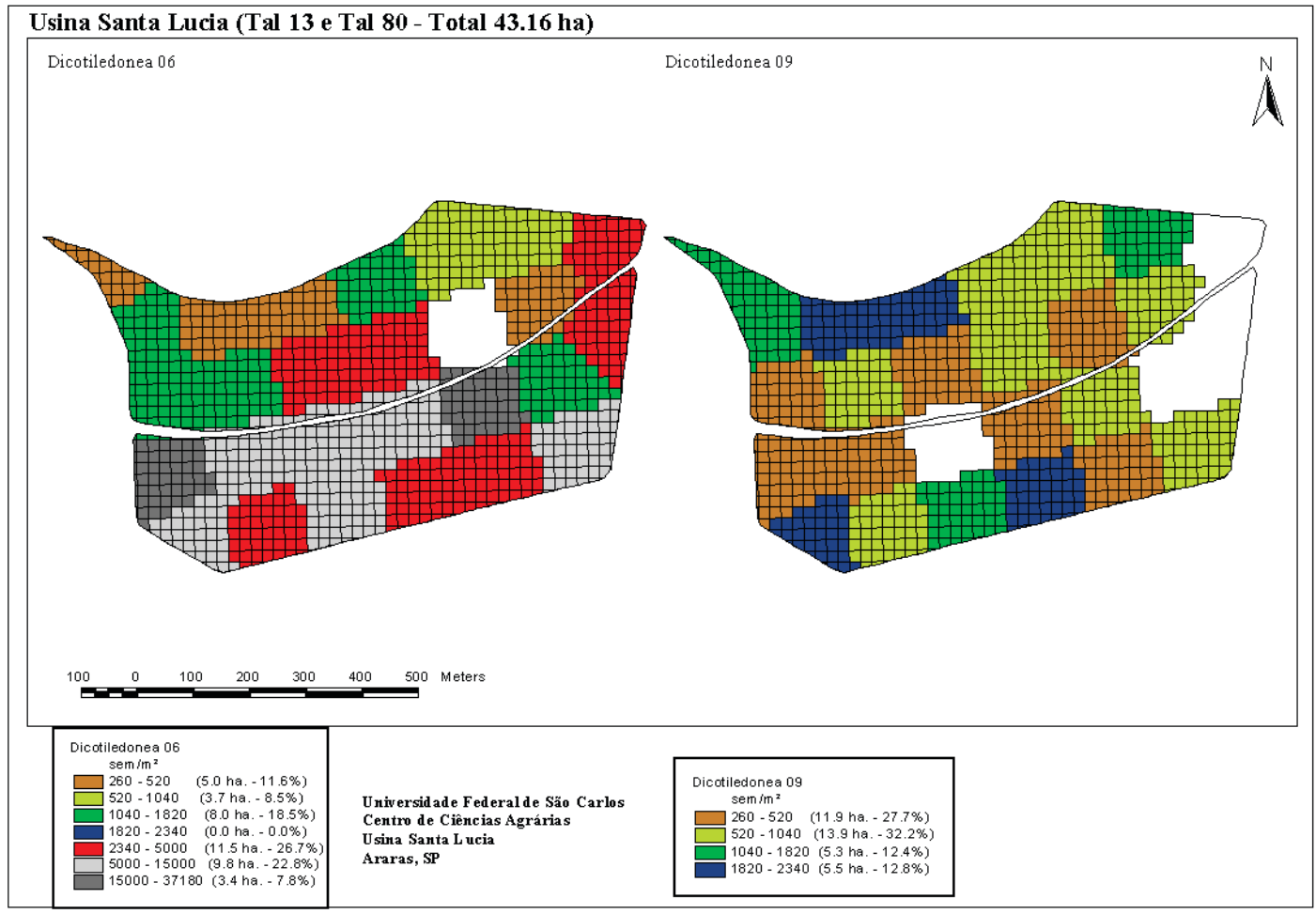

Figura 3 - Mapas de infestação de dicotiledôneas em área cultivada com cana-de-açúcar em sistema de cana-crua, em 2006 e 2009. 


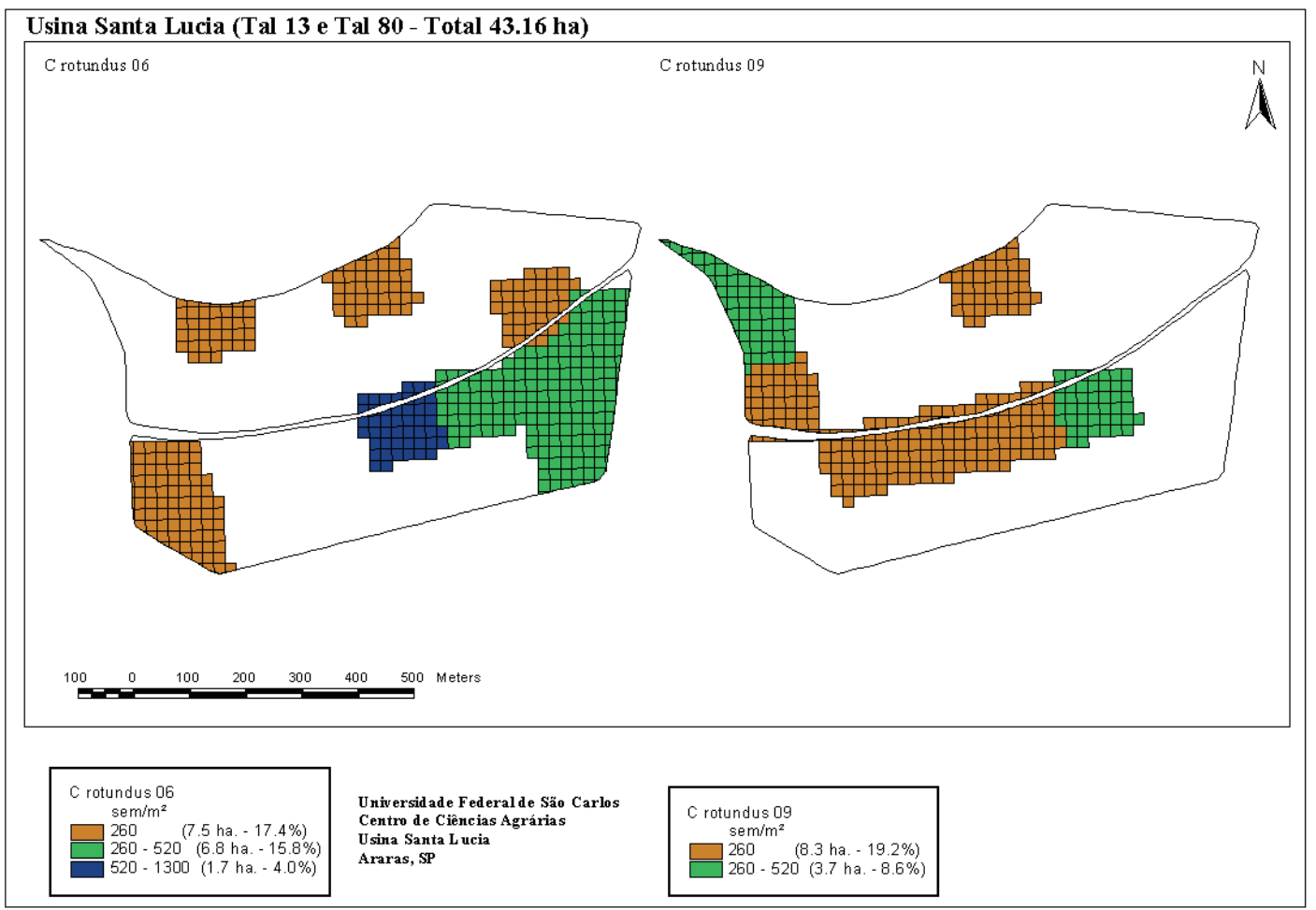

Figura 4 - Mapas de infestação de C. rotundus em 2006 e 2009.

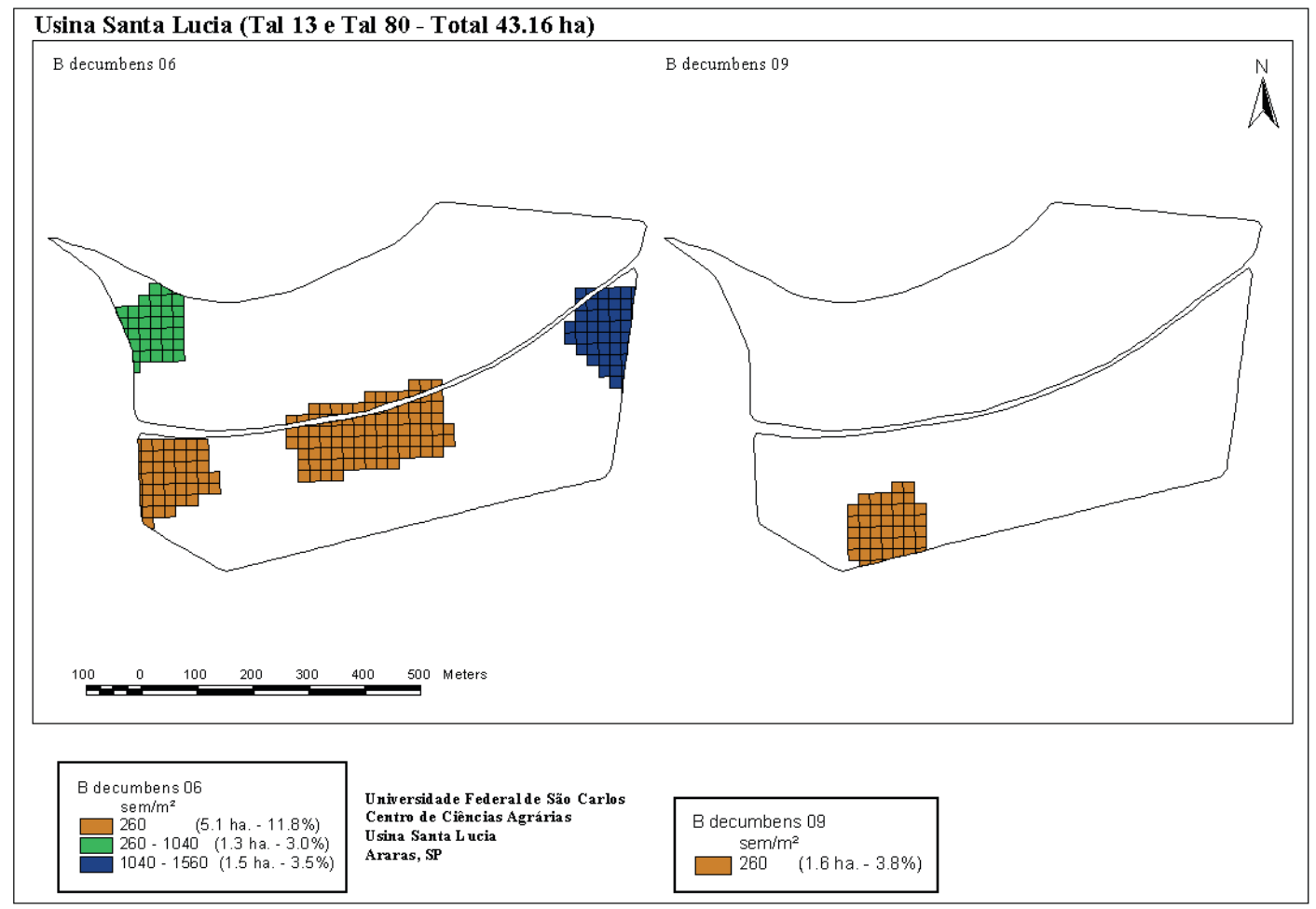

Figura 5 - Mapas de infestação de B. decumbens em 2006 e 2009 
$\mathrm{Na}$ avaliação das espécies dicotiledôneas separadamente, verificou-se que Amaranthus hybridus, em 2006, concentrou-se no talhão com colheita manual, com infestação variando de 260 a 2.340 sementes viáveis $\mathrm{m}^{-2}$ (Figura 6). No talhão com colheita mecanizada, verificaram-se apenas pequenas reboleiras de no máximo 260 sementes viáveis $\mathrm{m}^{-2}$. Em 2009, observou-se redução no banco de sementes dessa espécie na área que passou a ser colhida mecanicamente há um ano $(260$ a 1.040 sementes $\mathrm{m}^{-2}$ ), e ela praticamente não foi encontrada no talhão com colheita mecanizada há seis anos. Gravena et al. (2004) verificaram que a presença de palha de canade-açúcar sobre o solo suprimiu satisfatoriamente populações de $A$. hybridus.

Na Figura 7 pode ser observada a dinâmica da espécie Amaranthus retroflexus no período de 2006 a 2009. Em 2006, a espécie apresentava-se distribuída em todo o talhão com queima prévia da cana; a maioria da área apresentou infestação de 260 a 52.000 sementes $\mathrm{m}^{-2}$ e reboleiras de 7.800 a 20.540 sementes $\mathrm{m}^{-2}$. Todavia, na área colhida mecanicamente a infestação foi expressivamente menor. Em 2009, na área com apenas um ano de colheita mecanizada houve drástica redução da infestação dessa espécie, e ela desapareceu na área com maior tempo de implantação da colheita mecanizada. Carvalho et al. (2006) avaliaram diferentes espécies de Amaranthus, constatando que há diferenças de suscetibilidade entre elas aos herbicidas aplicados em pós-emergência, principalmente ao trifloxysulfuron e ao chlorimuron; $A$. deflexus foi a espécie menos suscetivel, seguida por A. spinosus, A. viridis, A. hybridus e $A$. retroflexus. Segundo esses autores, a suscetibilidade diferencial de espécies de plantas daninhas a herbicidas tem implicações diretas sobre o manejo a ser utilizado nas culturas agricolas. As diferenças interespecíficas de suscetibilidade exigem a correta identificação das espécies que ocorrem nas áreas agrícolas, sobretudo quando em estádio de plântulas, com necessidade da precisa escolha dos herbicidas que serão aplicados. Apesar de a maior parte da área apresentar em torno de $15 \mathrm{t} \mathrm{ha}^{-1} \mathrm{de}$ palha, essa quantidade variou de 5 a $15 \mathrm{t} \mathrm{ha}^{-1}$, permitindo que a germinação de sementes de plantas daninhas ocorresse em determinados pontos da área. Desse modo, para que o controle de espécies sensiveis à cobertura com palha fosse maximizado, seria necessário que o resíduo estivesse presente na quantidade necessária e regularmente distribuído sobre o solo. Velini \& Negrisoli (2000) relataram que a germinação de plantas daninhas ocorre em função das características do ambiente de dimensões bastante reduzidas $\left(\mathrm{cm}^{2}\right.$ ou $\left.\mathrm{mm}^{2}\right)$, inferindo ser nessa escala que a irregularidade ou regularidade da camada de palha deve ser avaliada.

Apesar do efeito supressor da palha da cana-de-açúcar sobre as espécies do gênero Amaranthus, o mesmo não foi verificado para as espécies Ipomoea grandifolia e I. purpurea (Figuras 8 e 9). Em 2006, constatou-se maior potencial de infestação de I. grandifolia no sistema de cana-crua (260 a 520 sementes viáveis $\mathrm{m}^{-2}$ ), em relação à com queima prévia (260 sementes viáveis $\mathrm{m}^{-2}$ ). Em 2009, a área com a presença de sementes viáveis dessas espécies foi visivelmente ampliada nos talhões com colheita mecanizada há apenas um ano, assim como no de seis anos, porém na área com cana-crua houve um período de tempo maior; por isso, o incremento na infestação foi mais elevado, evidenciando a seleção dessas plantas daninhas neste sistema de produção. A mesma tendência foi observada para a espécie I. purpurea. Silva et al. (2009) verificaram que a competição de plantas do gênero Ipomoea com a cana-de-açúcar tem potencial de redução do número final de colmos e da produtividade da cultura de 34 e $46 \%$, respectivamente. Gravena et al. (2004) constataram que o acúmulo de biomassa seca pelas plantas de Ipomoea foi maior na presença da palha de cana-de-açúcar. Segundo esses autores, esse resultado provavelmente ocorreu em virtude da redução da competição desta espécie com outras espécies que foram suprimidas pela presença de palha. De acordo com Kuva et al. (2007), os herbicidas ou métodos de controle para uso em cana-crua deverão apresentar, além de capacidade de passagem pela palha, eficiência de controle sobre $C$. rotundus e as diversas espécies de corda-de-viola.

Martins et al. (1999) constataram que a cobertura do solo com 5,10 e $15 \mathrm{t} \mathrm{ha}^{-1}$ de palha de cana inibiu a emergência de plântulas das espécies $B$. decumbens e Sida spinosa, sendo 


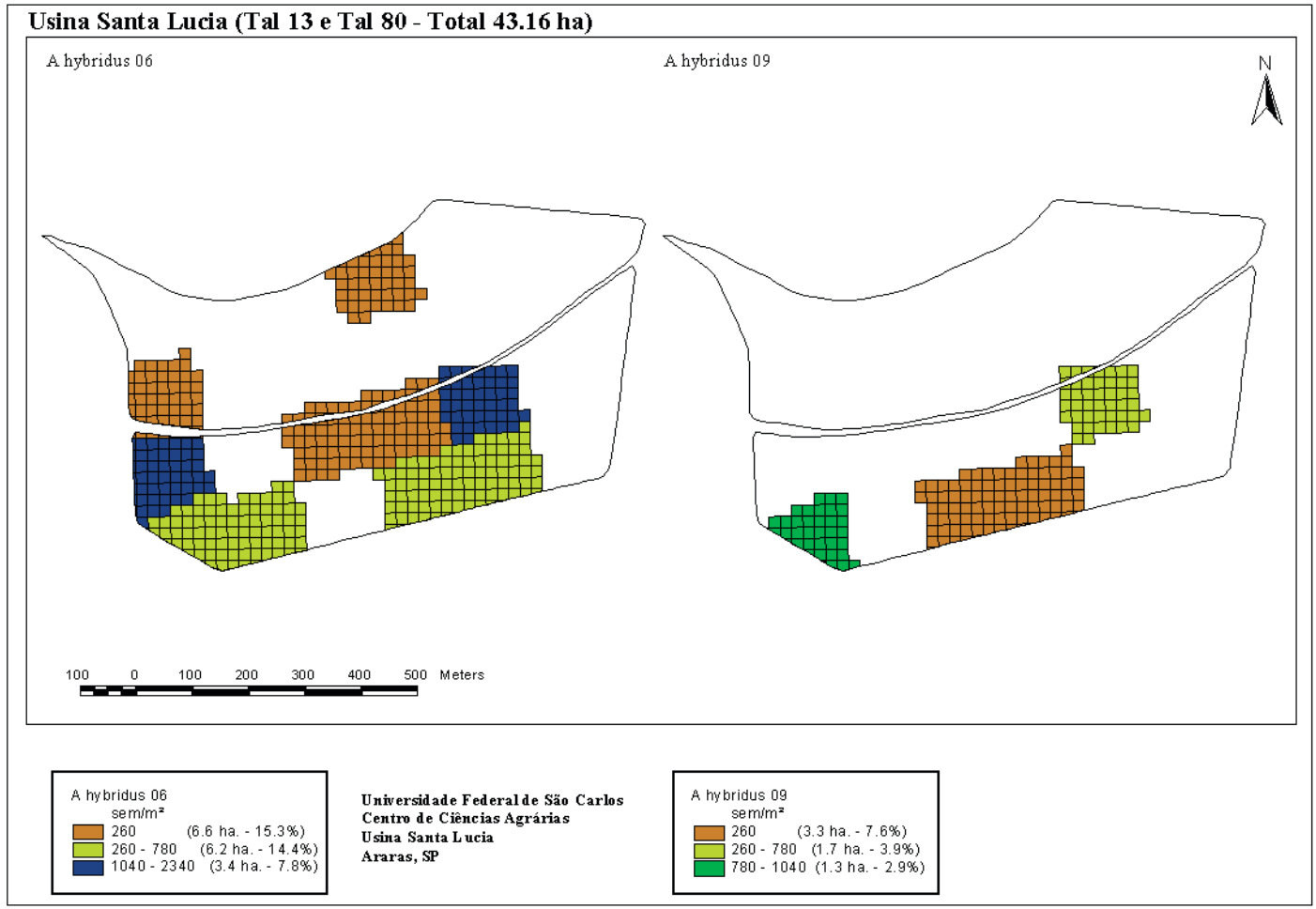

Figura 6 - Mapas de infestação de A. hybridus em 2006 e 2009.

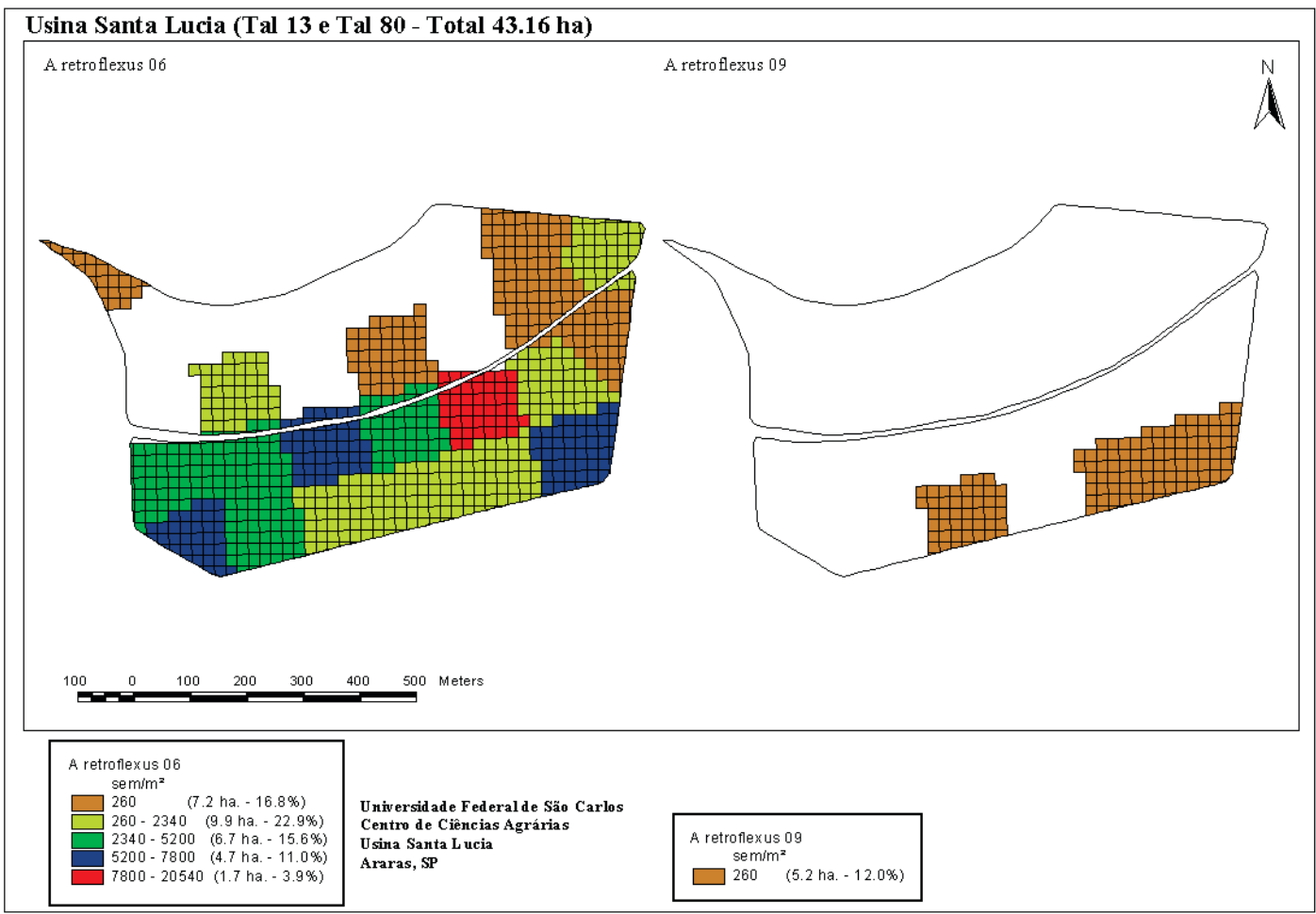

Figura 7 - Mapas de infestação de A. retroflexus em 2006 e 2009. 


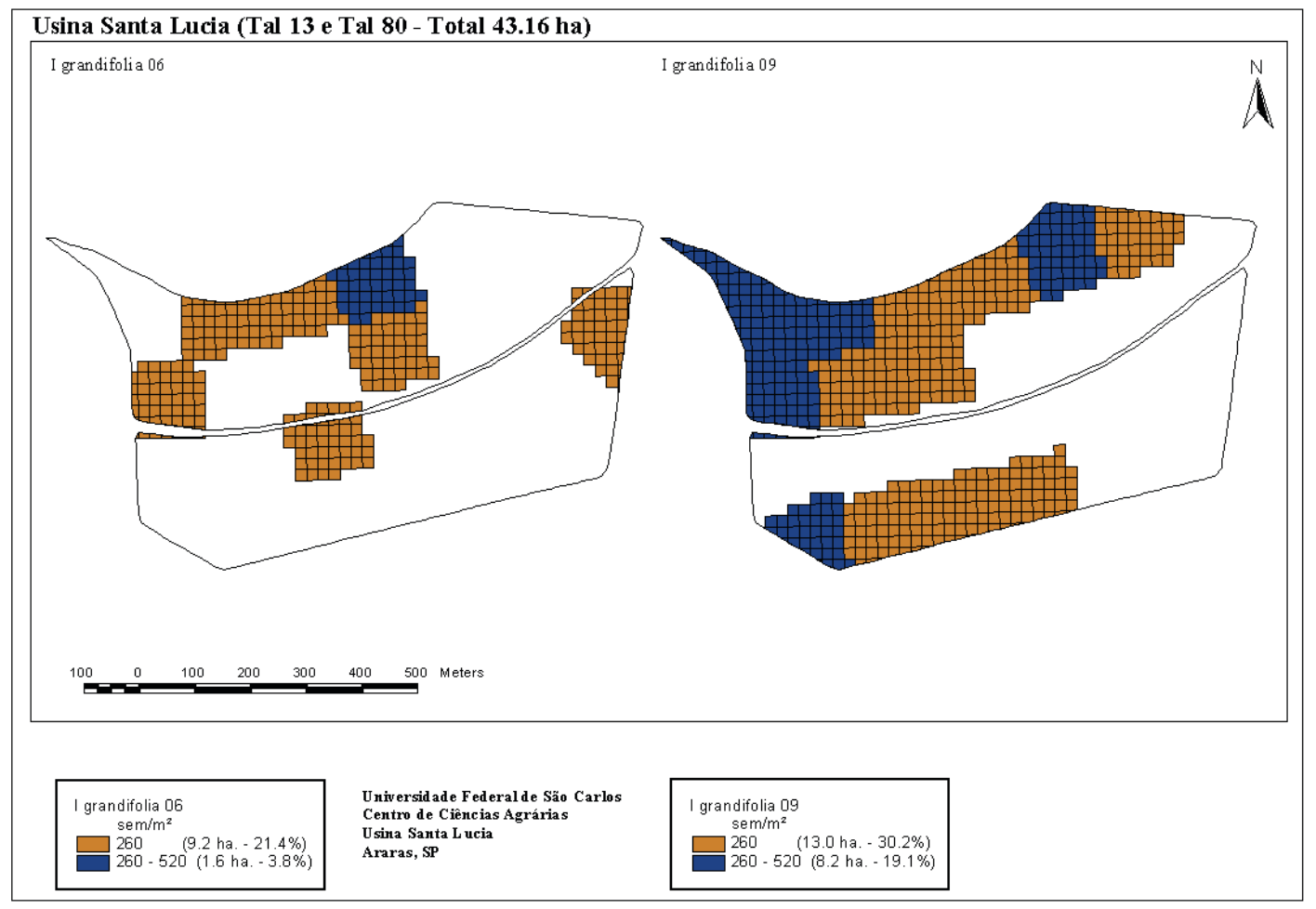

Figura 8 - Mapas de infestação de I. grandifolia em 2006 e 2009.

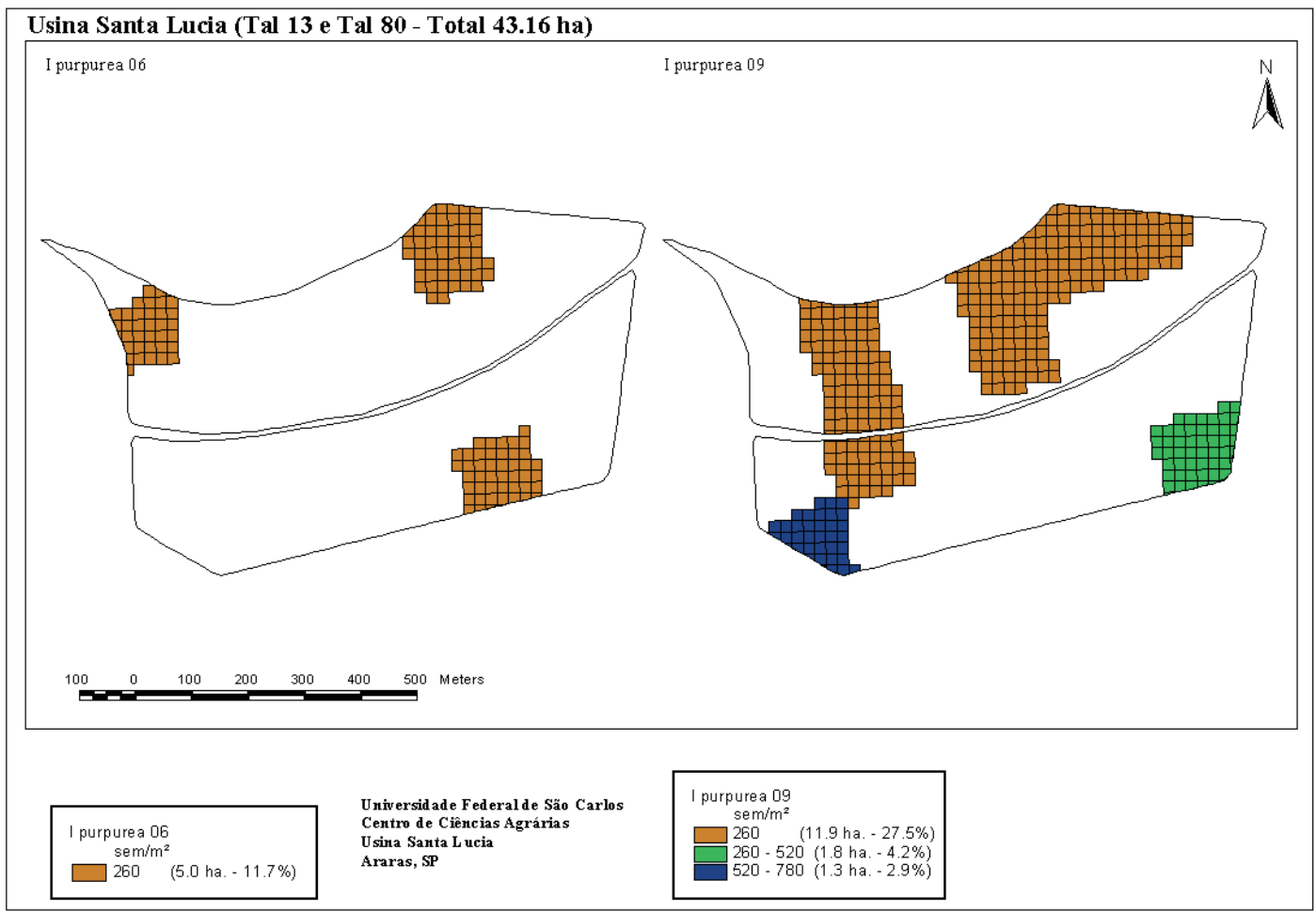

Figura 9 - Mapas de infestação de I. purpurea em 2006 e 2009. 
o mesmo observado para Digitaria horizontalis submetida a 10 e $15 \mathrm{t}$ ha ${ }^{1}$ de palha. No entanto, para I. grandifolia e I. hederifolia o número de plantas emersas não diferiu entre as quantidades de palha. Por outro lado, Correia \& Durigan (2004) constataram que a presença da cobertura morta com palha de cana incrementou a emergência de plântulas de I. quamoclit.

Na Figura 10 pode ser observado o comportamento da espécie E. heterophylla nos diferentes sistemas de colheita da cana-deaçúcar. Em 2006, essa espécie estava presente apenas no talhão colhido mecanicamente. Em 2009, ela foi encontrada em ambos os talhões (Figura 10). O aparecimento da espécie no talhão com apenas um ano de colheita mecanizada pode ter sido ocasionado pela redução da competição com outras espécies que foram suprimidas pela presença de palha. Kuva et al. (2007) também destacaram a familia Euphorbiaceae, com importância em canaviais colhidos no sistema mecanizado.
Quanto à espécie Lepidium virginicum, em 2006, no talhão colhido manualmente, após a queima, foram encontradas de 260 a 6.240 sementes $\mathrm{m}^{-2}$; já quando este talhão passou a ser colhido mecanicamente, houve redução significativa na infestação. $O$ talhão com cana-crua há mais tempo apresentou de 260 a 1.820 sementes $\mathrm{m}^{-2}$ em 2009, ligeiramente superior ao que foi constatado em 2006; todavia, observando-se a flora emergida, não foi uma planta daninha com expressão nessa área (Figura 11).

Para Portulaca oleracea e $P$. tenellus, a redução foi ainda mais drástica, como pode ser observado nas Figuras 12 e 13. Essas plantas apresentam sementes pequenas, o que explica o efetivo controle exercido pela palha. As sementes de $P$. oleracea apresentam de 0,5 a $0,8 \mathrm{~mm}$ de comprimento (Kissmann \& Groth, 2000), e as de $P$. tenellus, de 0,8 a $0,9 \mathrm{~mm}$ (Kissmann \& Groth, 1999a). Já as sementes de $E$. heterophylla apresentam comprimento de 2,5 a 3,0 $\mathrm{mm}$, e as de I. purpurea, de 4,0 a 4,4 mm (Kissmann \& Groth, 1999b).

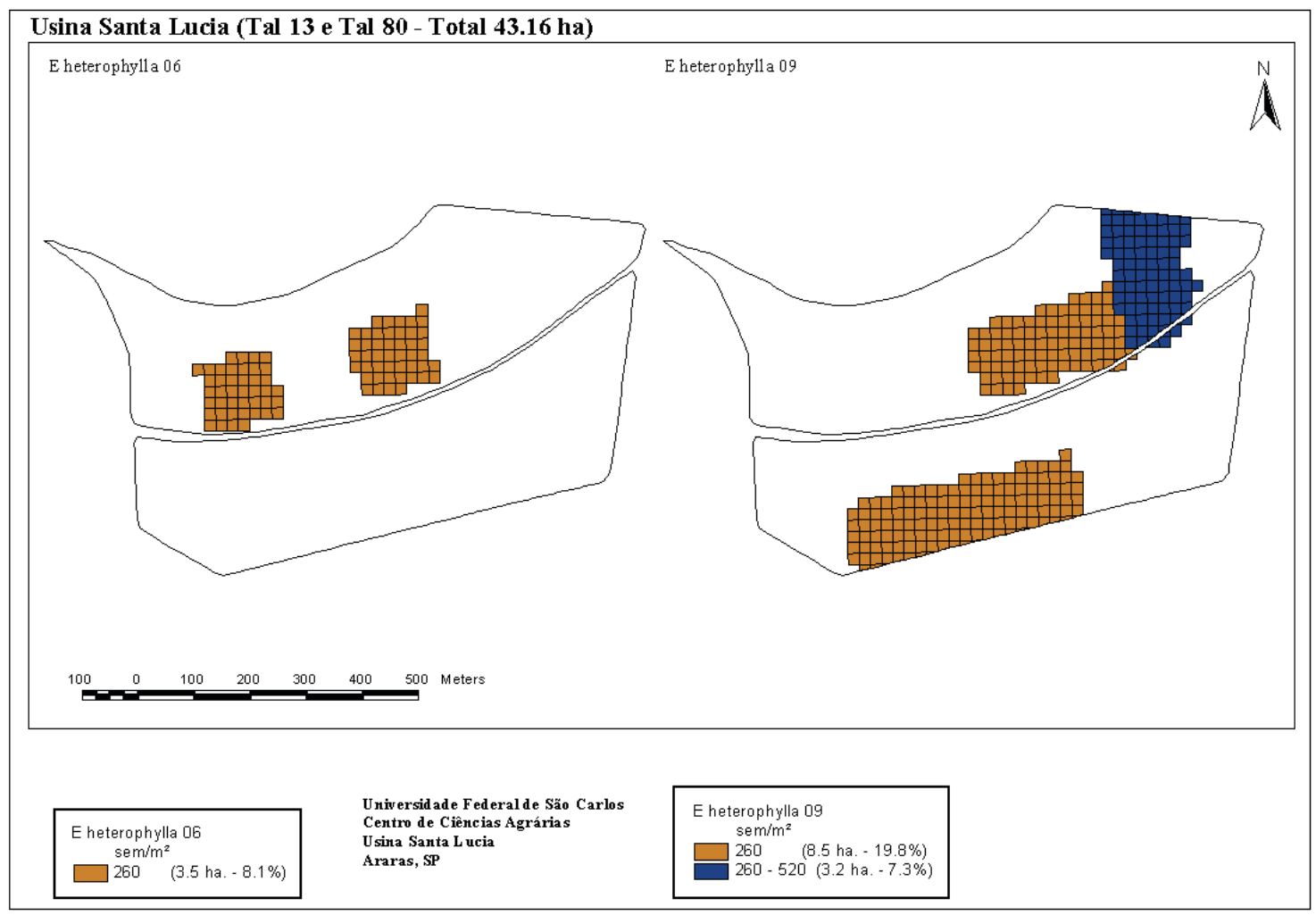

Figura 10 - Mapas de infestação de E. heterophylla em 2006 e 2009. 


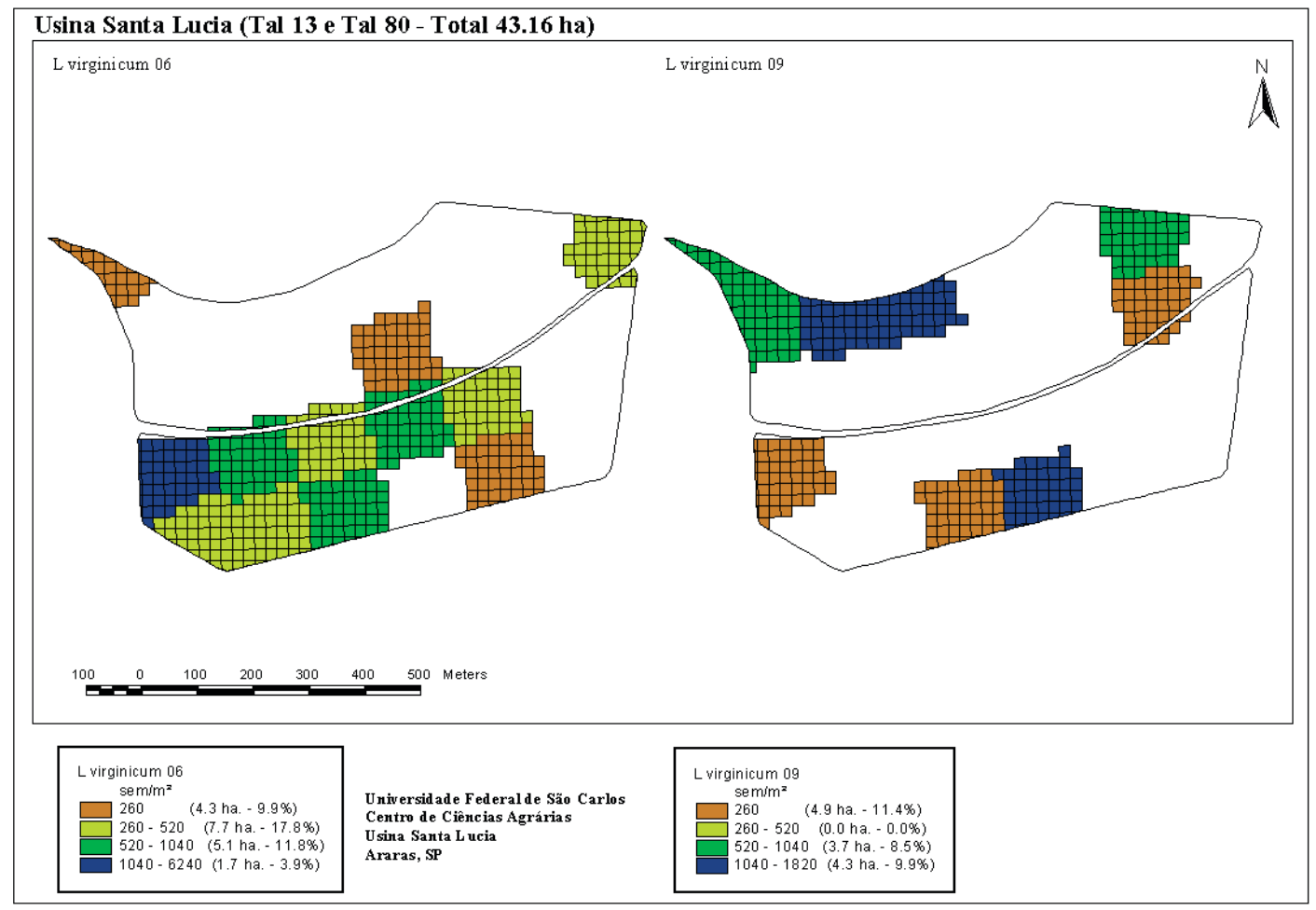

Figura 11 - Mapas de infestação de L. virginicum em 2006 e 2009.

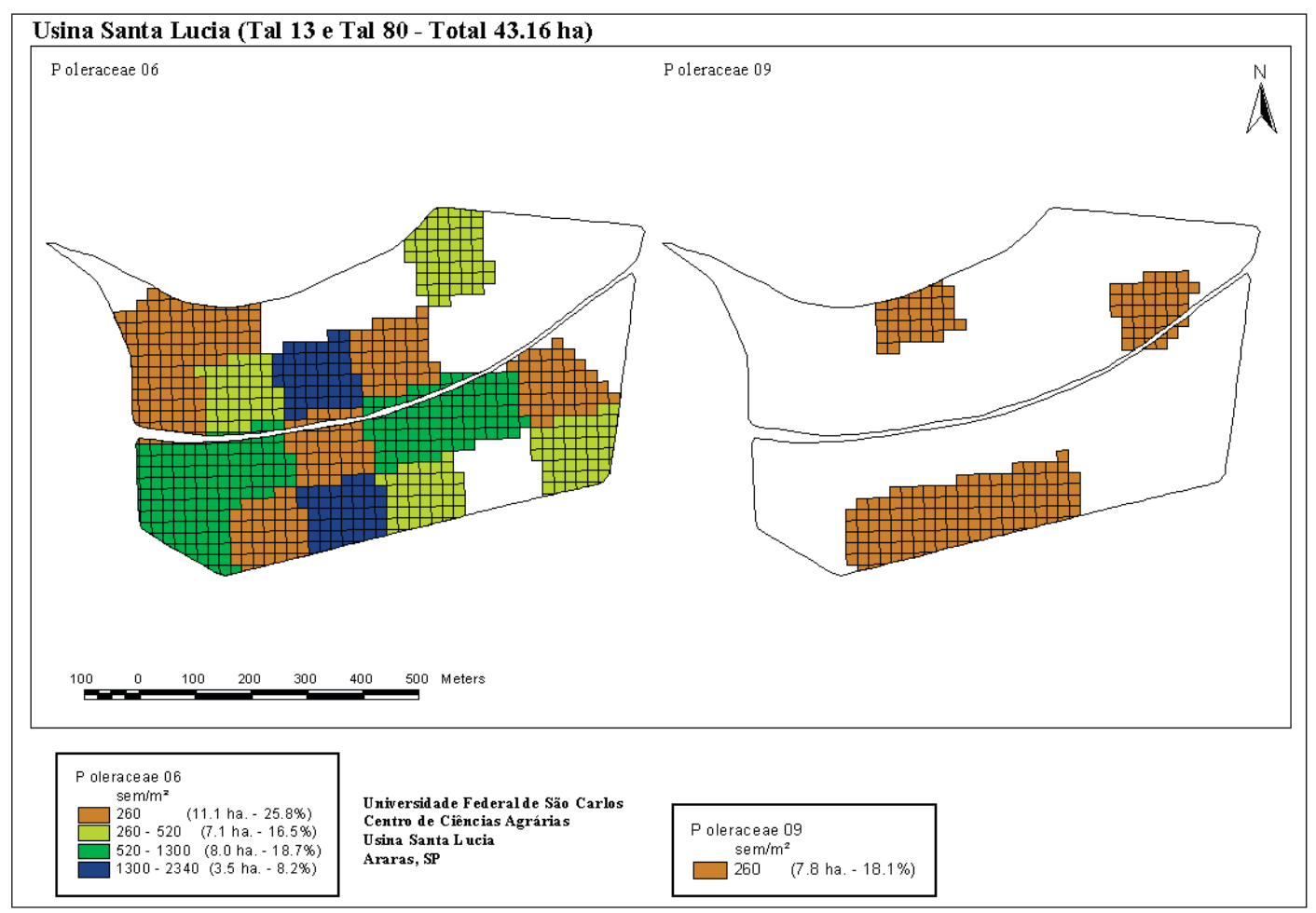

Figura 12 - Mapas de infestação de P. oleracea em 2003 e 2009. 


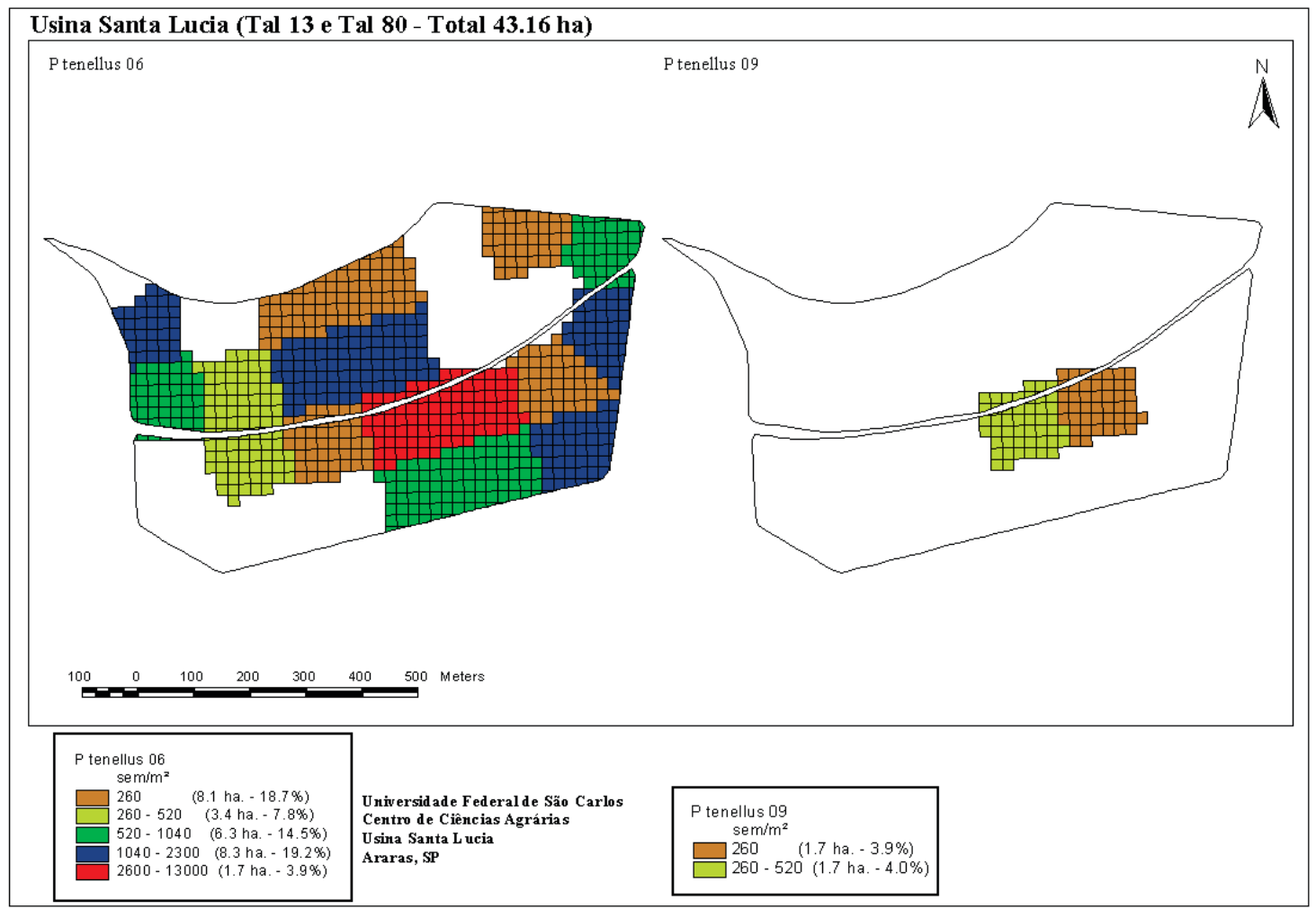

Figura 13 - Mapas de infestação de P. tenellus em 2006 e 2009.

Segundo Correia \& Durigan (2004), isso pode ser explicado pelo fato que a palha da canade-açúcar preservada proporciona cobertura do solo, o que dificulta a germinação de sementes de algumas espécies daninhas, pois ela reduz a penetração de luz no solo; pode ocorrer também a liberação de exsudatos da palha, com efeitos alelopáticos sobre a germinação de propágulos de plantas daninhas.

$O$ conjunto de resultados permite inferir que algumas espécies dicotiledôneas foram selecionadas no sistema de cana-crua, principalmente plantas dos gêneros Ipomoea e Euphorbia. Em relação às monocotiledôneas e dicotiledôneas provenientes de sementes pequenas, o controle da palha foi altamente eficaz, e as infestações ocorrem onde há irregularidade na distribuição da palha.

\section{LITERATURA CITADA}

AZANIA, A. A. P. M. et al. Interferência da palha de cana-deaçúcar (Saccharum spp.) na emergência de espécies de plantas daninhas da família Convolvulaceae. Planta Daninha, v. 20, n. 2 , p. $207-212,2002$
CARDINA, J.; SPARROW, D. H. A comparison of methods to predict weed seedling populations from the soil seedbank. Weed Sci., v. 44, n. 1, p. 46-51, 1996.

CARDINA, J.; JOHNSON, G. A.; SPARROW, D. H. The nature and consequence of weed spatial distribution.

Weed Sci., v. 45, n. 3, p. 364-373, 1997.

CARVALHO, S. J. P. et al. Suscetibilidade diferencial de plantas daninhas do gênero Amaranthus aos herbicidas trifloxysulfuron-sodium e chlorimuron-ethy.

Planta Daninha, v.24, n. 3, p. 541-548, 2006.

CONSTANTIN, J.; OLIVEIRA JUNIOR, R. S. Dessecação antecedendo a semeadura direta pode afetar a produtividade. Inf. Agron., n. 109, p. 14-15, 2005.

CORREIA, N. M.; DURIGAN, J. C. Emergência de plantas daninhas em solo coberto com palha de cana-de-açúcar.

Planta Daninha, v. 22, n. 1, p. 11-17, 2004.

DURIGAN, J. C.; TIMOSSI, P. C.; LEITE, G. J. Controle químico da tiririca (Cyperus rotundus), com e sem cobertura do solo pela palha de cana-de-açúcar. Planta Daninha, v. 22, n. 1, p. 127-135, 2004.

GOMES JR., F. G. \& CHRISTOFFOLETI, P. J. Biologia e manejo de plantas daninhas em áreas de plantio direto.

Planta Daninha, v. 26, n. 4, p. 789-798, 2008. 
GRAVENA, R. et al. Controle de plantas daninhas através da palha de cana-de-açúcar associada à mistura dos herbicidas trifloxysulfuron-sodium + ametrina. Planta Daninha, v. 22, n. 3, p. 419-427, 2004.

KISSMANN, K. G; GROTH, D. Plantas infestantes e nocivas. 2.ed. São Paulo: BASF, 1999a. Tomo II. 978 p.

KISSMANN, K. G;; GROTH, D. Plantas infestantes e nocivas. 2.ed. São Paulo: BASF, 1999b. Tomo III. 726 p.

KISSMANN, K. G; GROTH, D. Plantas infestantes e nocivas. 2.ed. São Paulo: BASF Brasileira, 2000. v. 3. p. 159162.

KREMER, R. J.; SPENCER, N. R. Impact of a seed-feeding insect and microorganisms on velvetleaf (Abutilon theophrasti) seed viability. Weed Sci., v. 37, n. 2, p. 211-216, 1989

KUVA, M. A. et al. Fitossociologia de comunidades de plantas daninhas em agroecossistema cana-crua.

Planta Daninha, v. 25, n. 3, p. 501-511, 2007.

LUSCHEI, E. C.; BUHLER, D. D.; DEKKER, J. H. Effect of separating giant foxtail (Setaria faberi) seeds from soil using potassium carbonate and centrifugation on viability and germination. Weed Sci., v. 46, n. 5, p. 545-548, 1998

MACIEL, C. D. G.; VELINI, E. D. Simulação do caminhamento da água da chuva e herbicidas em palhadas utilizadas em sistemas de plantio direto. Planta Daninha, v. 23 , n. 3 , p. $471-481,2005$.

MARTINS, D. et al. Emergência em campo de dicotiledôneas infestantes em solo coberto com palha de cana-de-açúcar. Planta Daninha, v. 17, n. 1, p. 151-161, 1999.

MEDEIROS, D. Efeito da palha de cana-de-açúcar sobre o manejo de plantas daninhas e dinâmica do banco de sementes. 2001. 125 f. Dissertação (Mestrado em Produção Vegetal) - Escola Superior de Agricultura Luiz de Queiroz, Piracicaba, 2001

MONQUERO, P. A. et al. Mapas de infestação de plantas daninhas em diferentes sistemas de colheita da cana-de-açúcar. Planta Daninha, v. 26, n. 1, p. 47-55, 2008

NOVO, M. C. S. S. Efeito da palha de cana-de-açúcar e do tamanho de tubérculos no desenvolvimento da tiririca (Cyperus rotundus). 2004. $107 \mathrm{f}$. Tese (Doutorado em Produção Vegetal) - Escola Superior de Agricultura "Luiz de Queiroz", Piracicaba, 2004.

PAES, J. M. V.; REZENDE, A. M. Manejo de plantas daninhas no sistema plantio direto na palha. Inf. Agropec., v. 22, n. 208 , p. $37-42,2001$.
PITELLI, R. Plantas daninhas no sistema plantio direto de culturas anuais. R. Plantio Direto, n. 4, p. 13-18, 1998.

RUEDELL, J. Plantio direto na região de Cruz Alta. Cruz Alta: FUNDACEP FECOTRIGO, 1995. 134 p

SEVERINO, F. J.; CHRISTOFFOLETI, P. J. Banco de sementes de plantas daninhas em solo cultivado com adubos verdes. Bragantia, v. 60, n. 3, p. 201-204, 2001.

SILVA, I.A.B. et al. Interferência de uma comunidade de plantas daninhas com predominância de Ipomoea hederifolia na cana-soca. Planta Daninha, v. 27, n. 2, p. 265-272, 2009.

SILVA, J. R. V.; COSTA, N. V.; MARTINS, D. Efeito da palha de cultivares de cana-de-açúcar na emergência de Cyperus rotundus. Planta Daninha, v. 21, n. 3, p. 375-380, 2003

SIMONI, F. et al. Eficácia de imazapic e sulfentrazone sobre Cyperus rotundus em diferentes condições de chuva e palha de cana-de-açúcar. Planta Daninha, v. 24, n. 4, p. 769-778, 2006.

THEISEN, G;; VIDAL, R. A. Efeito da cobertura do solo com resíduos de aveia-preta nas etapas do ciclo de vida do capim marmelada. Planta Daninha, v. 17, n. 2, p. 189-196, 1999.

TIMOSSI, P. C.; DURIGAN, J. C. Manejo de convolvuláceas em dois cultivares de soja semeada diretamente sob palha residual de cana crua. Planta Daninha, v. 24, n. 1, p. 91-98, 2006.

TRIVELIN, P. C. O. et al. Utilização por soqueira de cana-deaçúcar de safra do nitrogênio da aquamônia-15N e uréia-15N aplicado ao solo em complemento a vinhaça. Pesq. Agropec. Bras., v. 31, n. 1, p. 89-99, 1996.

ÚNICA. Produção de cana-de-açúcar, álcool e açúcar em 2008/2009. Disponível em: http://www.unica.com.br/ downloads/estatisticas/ranking0809.xls. Acesso em: 8 de set. de 2009 .

VASCONCELOS, A. C. M. Desenvolvimento do sistema radicular da parte aérea de socas de cana-de-açúcar sob dois sistemas de colheita: crua mecanizada e queimada manual. 2002. 140 f. Tese (Doutorado em Produção Vegetal) Universidade Estadual Paulista, Jaboticabal, 2002

VELINI, E. D.; NEGRISOLI, E. Controle de plantas daninhas em cana crua. In: CONGRESSO BRASILEIRO DA CIÊNCIA DAS PLANTAS DANINHAS, 22., 2000, Foz do Iguaçu. Palestras... Foz do Iguaçu: 2000. p. 148-164.

VIDAL, R. A.; THEISEN, G. Efeito da cobertura do solo sobre a mortalidade de sementes de capim-marmelada em duas profundidades no solo. Planta Daninha, v. 17, n. 3, p. 339-344, 1999. 